\title{
Biodiversity and temporal distribution of Chroococcales (Cyanoprokaryota) of an arid mangrove on the east coast of Baja California Sur, Mexico
}

\author{
Hilda León-Tejera ${ }^{1,}$, Claudia J. Pérez-Estrada², Gustavo Montejano ${ }^{1}$ \& Elisa \\ SERVIERE-ZARAGOZA ${ }^{2}$
}

${ }^{1}$ Department of Biology, Faculty of Sciences, Universidad Nacional Autónoma de Mexico, Apartado Postal 04360 , Coyoacán, Mexico,D.F. 04510, Mexico.hileont@gmail.com

${ }^{2}$ Centro de Investigaciones Biológicas del Noroeste, S.C. (CIBNOR), Mar Bermejo 195, Col. Playa Palo de Santa Rita, La Paz, B.C.S. 23090, Mexico

\begin{abstract}
Arid mangroves constitute a particular biotope, with very extreme variations in ecological conditions, mainly temperature and salinity, condition that demand specific adaptations to successfully inhabit this ecosystem. Cyanoprokaryotes have not been well studied in Mexican coasts and this is the first study that contributes to the knowledge of the biodiversity of this group in an arid mangrove in Zacatecas estuary, Baja California Sur, Mexico. Samples of Avicennia germinans pneumatophores from Zacatecas estuary were collected between May 2005 and May 2006. The identification of the most representative Chroococcales produced 10 morphotypes, described morphologically and digitally registered for the first time for Mexico. We report species of Aphanocapsa, Chroococcus, Hydrococcus, Chamaecalyx, Dermocarpella and Xenococcus. Some taxa have been recorded in brackish or even marine environments from other regions, evidencing the wide geographical distribution and ecological adaptability of these organisms, but some others are probably new to science. Some species have a specific seasonal and vertical distribution on the pneumatophore but other have a more ample distribution. Aphanocapsa littoralis and Chroococcus cf. obliteratus are new records for benthic biotopes of Pacific Mexico; Dermocarpella cf. stellata is a new record for the Gulf of California.
\end{abstract}

Key words: Arid region, Chroococcales, New records, Mangrove, Mexico

\section{Introduction}

Mangroves are one of the most biologically important ecosystems in the coastal areas, they play important ecological functions taking part in the stabilization of sediments, act as a natural barriers for big waves produced by hurricanes, tsunamis, etc., are an important source of nutrients, home to a large number of species of flora and associated fauna, and forming areas of breeding, rearing, feeding, growth and protection from predators for a great variety of organisms (FLORES-VERDUGO 1990; Dawes 1998; Mann 2000).

Furthermore, it is one of the most productive ecosystems in the world, functioning as natural traps of organic matter. Their productivity values vary with the type of primary producers (mangroves, microalgae and macroalgae) found in this ecosystems, the time of year and water physicochemical characteristics which depend in turn on the water circulation patterns, since this car- ries nutrients vertically and horizontally (TRAINOR 1988). Mangrove forest, common along many tropical and some subtropical coastal lagoons are inhabited by a diverse cyanoprokaryote community which reside on leaves, roots litter, live roots and often form extensive mats on the surrounding sediment (PotTs 1979, 1980; Pотts \& WhitTon 1980; Sheridan 1991; Phillips et al. 1994, 1996). Also, many of these communities are capable of $\mathrm{N}_{2}$ fixation (Toledo et al. 1995; HofFMANN 1999). There have been several studies in different parts of the world that describe epiphytic algal communities on pneumatophores, however the cyanoprokaryotes from Eastern Pacific mangroves have received little attention and only few species have been reported, mainly from order Oscillatoriales (Burkholder \& Almodovar 1973; Bashan et al. 1988; Rodriguez \& Stoner 1990; Phillips et al. 1994, 1996; Toledo ET AL. 1995A; Branco et al. 1996; LAURSEN \& King 2000; NogueIra \& FERrEIRA-Correia 2001; TEJADA-Rivas 2002; Barrios et 
al. 2003; Baos-Estupiñan 2007; PeÑa-SalamanCA 2008; CRUZ-MADRID 2010).

In Mexico, there is a lack of knowledge on coastal Cyanoprokaryotes. In recent years, a more detailed and comprehensive study of marine, mainly epiphytic and epilithic Cyanoprokaryote populations (León-Tejera \& Montejano 2000; Montejano \& León-Tejera 2002; León-Tejera et al. 2003; LEÓN-TeJERA et al. 2005) has been developed, but studies that focus specifically on mangroves are scarce. Toledo et al. (1995a) determined the vertical zonation of cyanoprokaryotes on pneumatophores of Avicenia germinans (L.) Stearn L. in Bahia Balandra, Baja California Sur, Mexico finding that the bottom part, close to the sediment was colonized mainly by non-heterocystous, filamentous cyanoprokaryotes resembling Lyngbya sp. and Oscillatoria sp.;

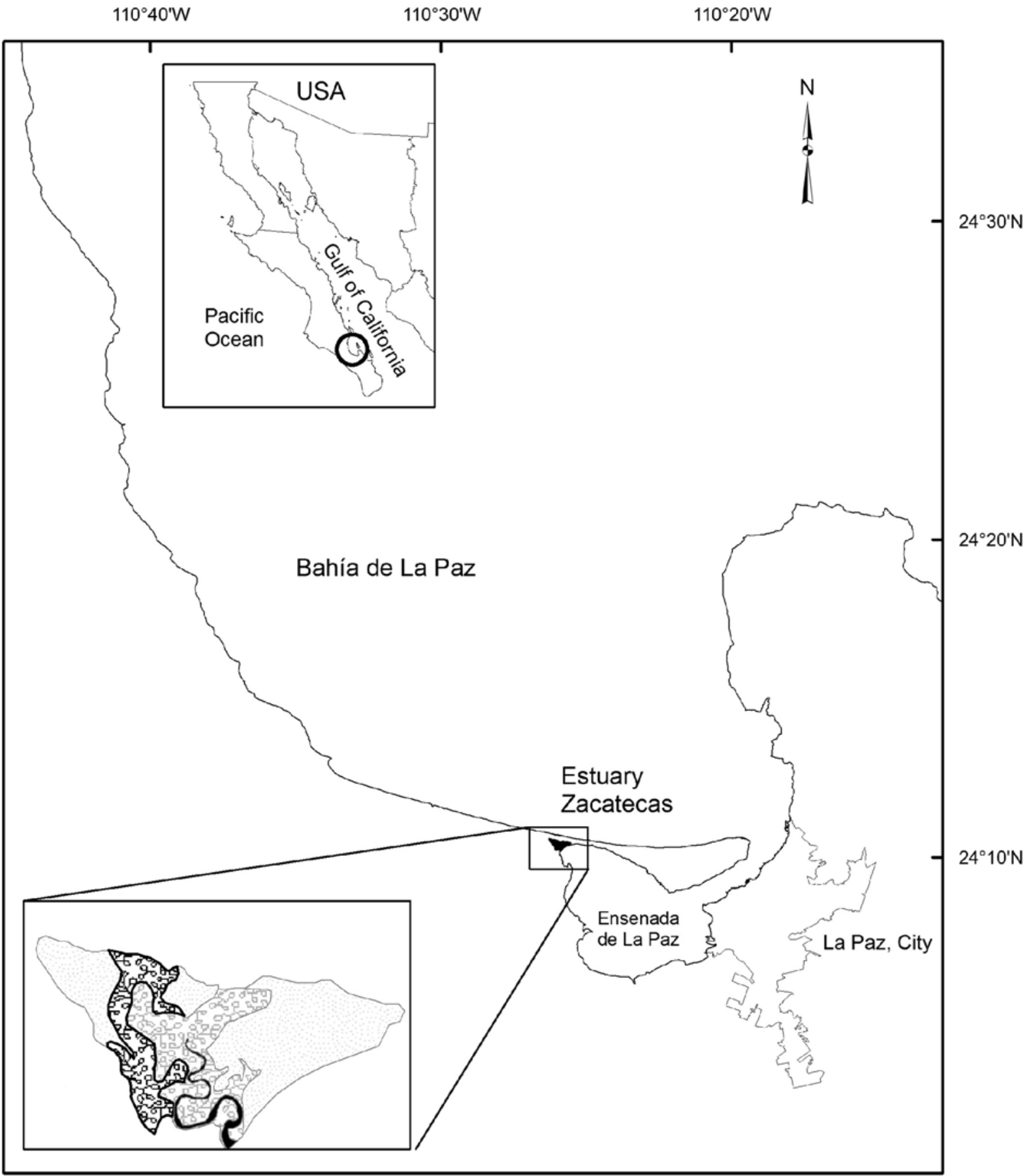

Fig. 1. Map of study area, showing location of Zacatecas estuary in Baja California Sur, Mexico, AG: Avicenia germinans fringe mangrove. 
the central zone mainly by filaments resembling Microcoleus sp. and the upper part by colonies resembling Aphanothece sp. mixed with indeterminate filamentous cyanoprokaryotes. Holguin et al. (1999) inoculated experimentally mangrove seedlings with Microcoleus sp. and demonstrated that the mangrove assimilate the nitrogen fixed by Microcoleus sp. (BAshan et al. 1988). In this biotope, the main $\mathrm{N}_{2}$ fixers were cyanoprokaryotes (Toledo et al. 1995b), implying that interaction of cyanoprokaryotes and mangrove seedlings is mutually beneficial and suggests the use of the first as inoculants for mangrove reforestation and rehabilitation.

This paper provides information on biodiversity of cyanoprokaryotes of the most conspicuous populations of order Chroococcales that grow on Avicennia germinans pneumatophores from $\mathrm{Za}-$ catecas estuary, Baja California Sur, Mexico, an arid mangrove located in the southwestern Gulf of California. Chroococcaleans are of special interest because several species had not been reported since Setchell \& Gardner $(1919,1924)$ and GARDNER (1918a, b) described them for the Pacific Coast of North America and Gulf of California. Zacatecas estuary represents the most northern mangrove distribution in the eastern Pacific; in a Gulf of California arid zone which does not have a constant supply of fresh water and rainfall. In this site, mangrove grow under suboptimal conditions, in strictly tidal saltwater and their communities are far shorter and less extensive than in other parts of the tropics (WhitMORE et al. 2005).

\section{Materials and Methods}

Zacatecas estuary $\left(24^{\circ} 10.359^{\prime} \mathrm{N} ; 110^{\circ} 26.080 \mathrm{~W}\right)$ is located in the Ensenada de La Paz, Baja California Sur, Mexico (Fig. 1). It occupies approximately 17 ha of mangrove forest (Rhizophora mangle L., Laguncularia racemosa L. GAERTN. and Avicennia germinans L.), and have a main flow tidal channel of $1.3 \mathrm{Km}$ long (ZAMORANO obs. pers.). Tidal regime was semidiurnal with an average tidal range $1.02 \mathrm{~m}$ and $1.74 \mathrm{~m}$ amplitude.

During samplings, temperature ranged from 17.45 to $32.19^{\circ} \mathrm{C}$ and salinity from 38.12 to 43.08 UPS, with almost no rain throughout the year, clearly classifying it as an arid type of mangrove.

In Zacatecas estuary pneumatophore samples were obtained along Avicennia germinans fringe from May 2005 to May 2006 (Fig. 1). Two pneumatophores were collected for each sample date and these were fixed in $4 \%$ formaldehyde in sea water at the site. The pneumatophores were washed with fresh water to remove sediment and organic matter. Conspicuous cyanoprokaryotes growths were scraped with a bisturi, and semi-permanent slides in glycerin gel were made. Observations, measurements and micrographs were made with an Olympus BX51 microscope and Sigma Scan Pro 5 software. KomÁreK \& ANAGNOSTIDIs (1998) system was used for the systematic of Chroococcales, Setchell \& Gardner (1924) and Guiry \& Guiry (2010) for macroalgae.

\section{Results}

We present the first report and morphological description of 10 species of chroococcalean cyanoprokaryotes from a Mexican arid mangrove. They belong to 6 families of the order Chroococcales: Merismopediaceae, Chroococcaceae, Hydrococcaceae, Chamaesiphonaceae, Dermocarpellaceae and Xenocococcaceae and represent the first records for these species populations for the Gulf of California. Nostocales and Oscillatoriales descriptions will be presented elsewhere.

A detailed morphological description with data on spatial and temporal distribution on pneumatophores is provided for the populations that were most conspicuous and presented different stages of their life cycle.

\section{Family Merismopediaceae ELENKIN 1933 Subfamily Merismopedioideae}

\section{Aphanocapsa littoralis (HANSGIRG) KOMÁREK et Anagnostidis 1995. (Fig. 2)}

Colonies obvovoidal, pseudospherical to irregular shape, formed by 30 or more cells contained in a sheath. Sheath homogeneous, hyaline, diffluent, up to $55 \mu \mathrm{m}$ in diameter, with an irregular and usually diffuse margin. Sometimes subcolonies formed by 4 or more cells are found within the main colony. Cells light green to blue-green, ovoid to spherical, $1-3.8 \times 1.3-2.7 \mu \mathrm{m}$ length/ wide $(1 / \mathrm{w})$, with a light centroplasm. Cells with individual hyaline sheaths, but sometimes not evident; length/wide 1.2-1.7 $\mu \mathrm{m}$. Cells divide by binary fission in 3 planes, with daughter cells growing to parental cell size before division.

Similar to A. littoralis (HANSGIRG) KomÁrek et Anagnostidis, sensu Crispino and Sant'Anna (2006) for Brazil, but cells are not as aggregat- 
ed as described by KomÁreK and Anagnostidis (1998); similar size to A. concharum (HANSGIRG), but it is not epizoic.

Reported for Mediterranean coasts, France, Norway, Baltic Sea and probably cosmopolite. First report for benthic biotopes of Pacific Mexico.

Occurrence: Found throughout all the year, from May 2005 to May 2006 near roots as well as in medium part of pneumatophores.

\section{Aphanocapsa sp. (Fig. 3)}

Colonies ovoid in shape, formed by a few, widely separated cells. Colonial sheath homogeneous, hyaline to yellowish, firm, up to $70 \mu \mathrm{m}$ in diameter, with a regular margin. Cells brownish to yellowish, ovoid to subspherical, 6-7 $\times 5-6 \mu \mathrm{m}$ in diameter, with a light centroplasm. Cells with evident individual sheaths; length/wide 1.1-1.2 $\mu \mathrm{m}$. Cells divide by binary fission in 2 planes, with daughter cells growing to parental cell size before division.

We distinguish this morphotype from $A$. littoralis because of a lack of subcolonies, as well as a larger cell size, color and wider cell to cell distance.

Occurrence: Reported for July and November 2005, as well as January 2006, growing near root pneumatophores.

\section{Family Chroococcaceae NägELI 1849}

\section{Chroococcus cf. obliteratus RICHTER 1886. (Fig.}

4)

Colonies of 2-4 cells hemispherical to a slightly rounded prism in shape, $6-8 \mu \mathrm{m}$ in diameter. Cells blue-green to slightly yellowish, without cytoplasmic granulations, separated and surrounded by an ample hyaline sheath, $2-3 \times 1-1.9 \mu \mathrm{m}$ in diameter. Colony sheath not lamellate, firm inside and diffluent outside. Reproduction by regular binary fission in 3 planes.

It differs from KoMÁREK and ANAGNOSTIDIS (1998) description in the presence of a defined colonial sheath and shorter cell size. Reported previously for brackish and freshwater biotopes, possibly cosmopolite. First report for benthic biotopes of Pacific Mexico.

Occurrence: Found throughout all the year, from May 2005 to May 2006, on the mucilage that covers different parts of the pneumatophores and epiphytic on Rhizoclonium sp.

\section{Chroococcus sp. 1 (Fig. 5)}

Colonies of 1-2 cells with both individual and colonial sheath hyaline and firm. Cells brownish with slightly granulated cytoplasm, ovoid to pyriform 18-20 × 10-14 $\mu \mathrm{m}$ in diameter, with sheath $20-28 \times 13-17 \mu \mathrm{m}$. Cells divide by binary fission mainly in 2 planes.

It differs from the latter species by its much longer cell size and different color.

Occurrence: It was found throughout the year, from May 2005 to May 2006, growing on the mucilage intermingled with Calothrix sp. and other coccal algae in different parts of the pneumatophore and epiphytic on Rhizoclonium sp.

\section{Chrococcus sp. 2 (Fig. 6)}

Colonies 64 x $45 \mu \mathrm{m}$ in diameter formed by a nested arrangement of smaller colonies 6-11 $\times$ $7-9 \mu \mathrm{m} 1 / \mathrm{w}$. Daughter colonies formed by $1-8$ cells resulting from three plane divisions. Mature cells, 5-6 × 3-6 $\mu \mathrm{m}$ with blue-green, homogeneous cytoplasm. Small colonies sheath firm, hyaline, whereas larger colony sheath is diffluent with many particles and other bacteria embedded. Cells divide before reaching the original cell size.

Occurrence: Found throughout all the year, from May 2005 to May 2006, in different parts of the pneumatophore, but with low frequency.

\section{Family Hydrococcaceae KütZING 1843}

\section{Hydrococcus sp. (Fig. 7)}

Colonies $25 \mu \mathrm{m}$ in diameter, formed by the aligned arrangement of erect pseudofilaments, forming discs that grow radially. Pseudofilaments 3-4 cells high, perpendicular to the substrate. In superior sight only discs are perceived. Cells mostly cylindrical to cubical in shape and apical ones hemispherical to irregular, with homogeneous blue-green cytoplasm, 1-2 × 1-1.2 $\mu \mathrm{m}$ long/wide without sheath. Cell sheath hyaline, evident, 0.2 to $0.7 \mu \mathrm{m}$ wide.

Not very well known group, with 4 species described. The three freshwater and only one marine species: $H$. marinus Grunow have cells several (up to 4-5) times larger. Very different in biotope, general colony aspect, cell size and morphology from descriptions and drawings of species previously described, therefore it is probably 

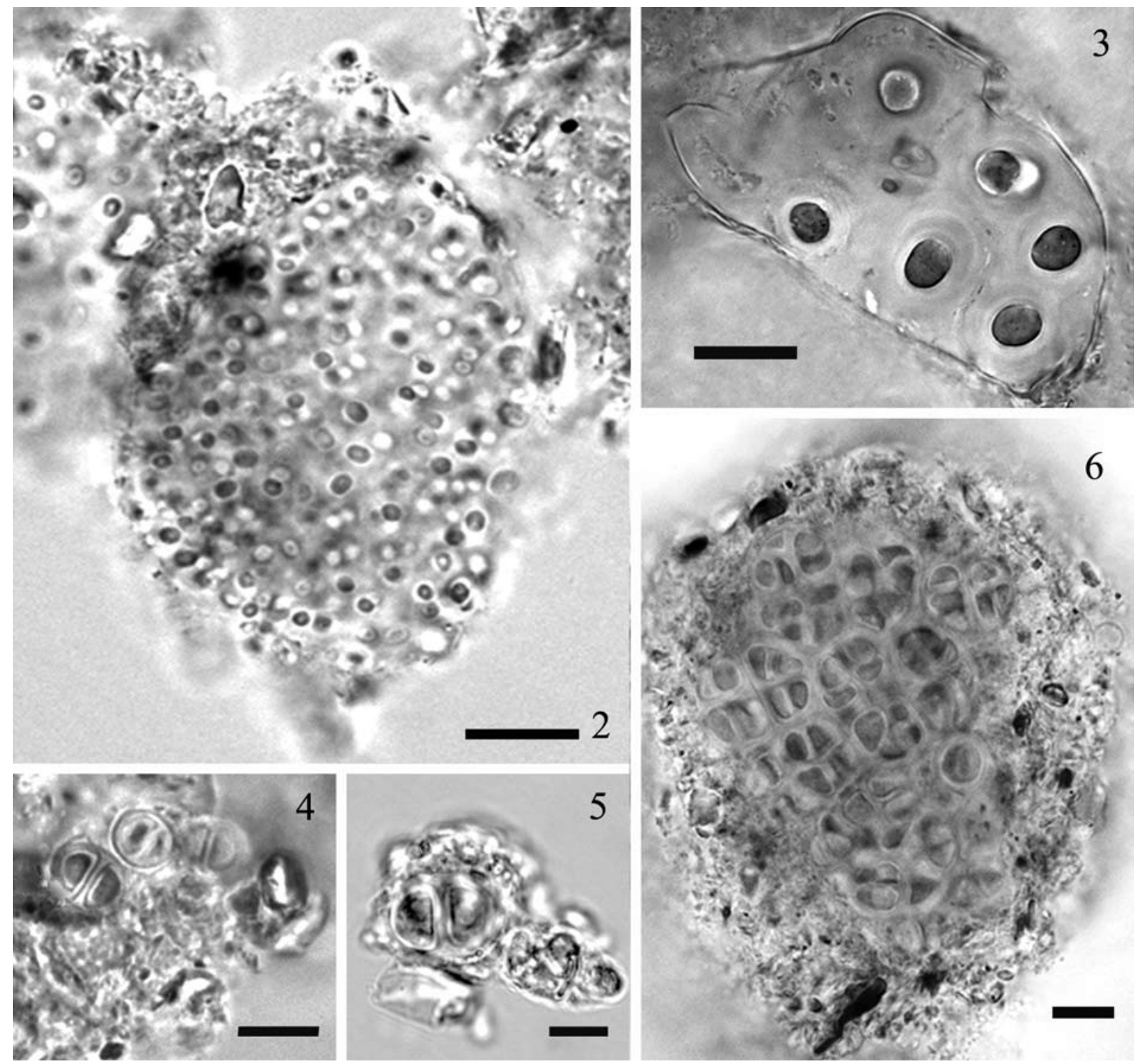

Fig. 2. Aphanocapsa littoralis (Hansgirg) Komárek et Anagnostidis 1995. Fig. 3. Aphanocapsa sp. Fig. 4. Chroococcus cf. obliteratus Richter 1886. Fig. 5. Chroococcus sp. 1. Fig. 6. Chrococcus sp. 2. Scale bar $10 \mu \mathrm{m}$.

a new species.

Occurrence: Found in October, November, 2005 and May 2006, not close to pneumatophore roots on Rhizoclonium sp.

\section{Family Chamaesiphonaceae Borzì 1882}

\section{Chamaecalyx sp. (Fig. 8)}

Heteropolar cell pyriform or maze shaped, isolated or in small groups. Mother cell blue-green, with very granulose cytoplasm, up to $30 \mu \mathrm{m}$ long with a firm and hyaline sheath, adhered to the substrate by a narrower base. Apical part 11-13 $\mu \mathrm{m}$ in diameter and basal part 6.7 to $9.2 \mu \mathrm{m}$ wide.
When undivided, the cell has maze shape; sometimes basal part is slightly thinned upwards and subsequently widens towards to the top. Initially cell divides parallel to the substrate 1-3 times producing 2-4 cells lengthwise oriented, and later perpendicular and irregular division planes occur, generating 6-8 exocytes.

Similar in cell size to Ch. leibeiniae (REINSCH) KomÁREK et ANAGNostidis, but cell shape is different and length/width reason is larger. $C h$. algarvensis (ARDRÉ) KOMÁREK et ANAGNOSTIDIS is different as it has much shorter cell size, is red and with many exocytes. Probably an undescribed species.

Species of this genus are reported for the Mediterranean sea, both sides of Atlantic and also 

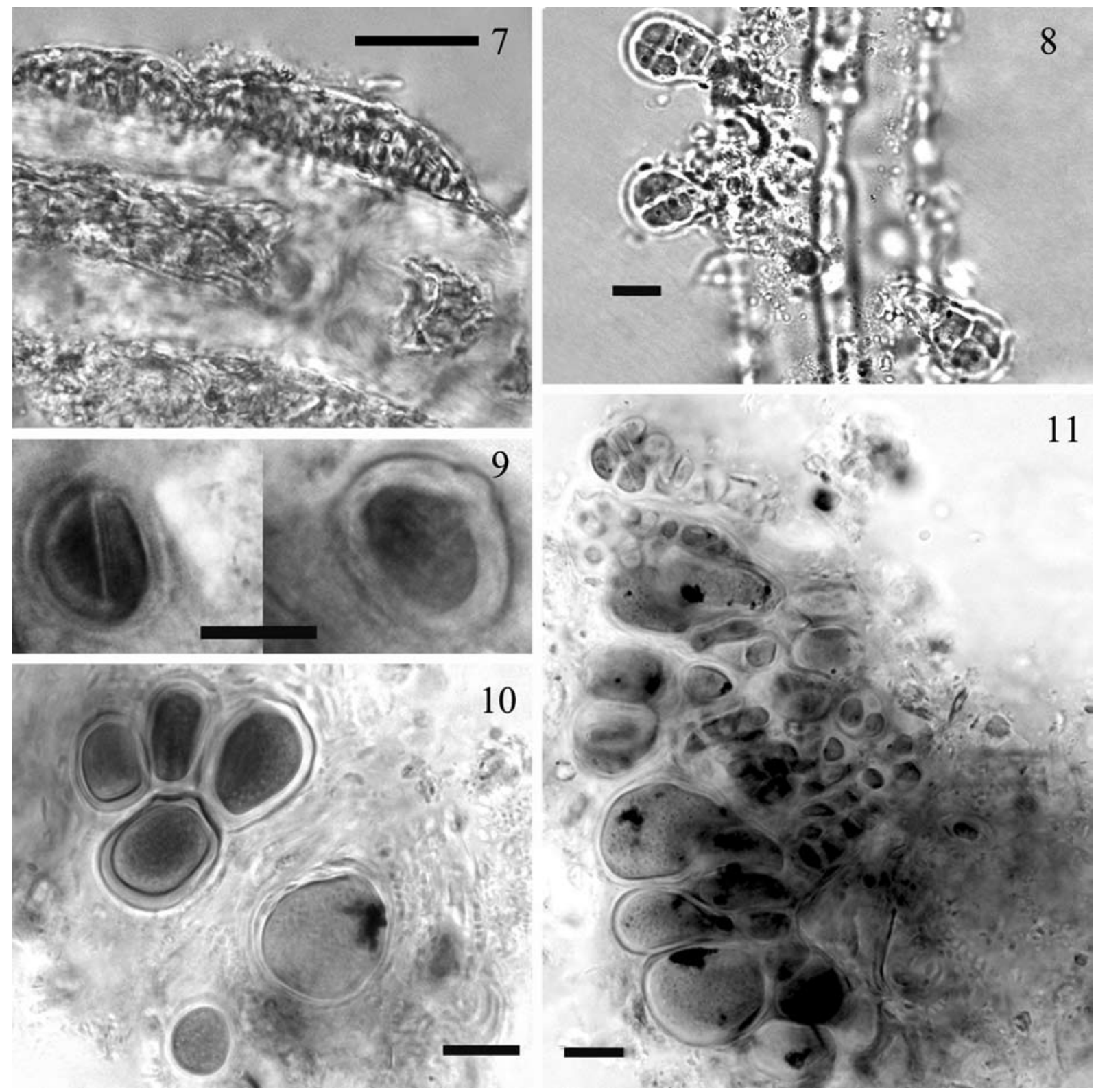

Fig. 7. Hydrococcus sp. Figs. 8. Chamaecalyx sp. Fig. 9. Dermocarpella cf. stellata Montejano et León 2000. Fig. 10. Xenococcus cf. chaetomorphae Setchell et Gardner 1918a. Fig. 11. Xenococcus sp. Scale bar $10 \mu \mathrm{m}$.

for the Pacific and Indic oceans.

Occurrence: Found throughout all the year, from May 2005 to May 2006, but more frequent in autumn (October 2005) and winter (January 2006), on Bostrychia sp. and Rhizoclonium sp., in different parts of the pneumatophore;

\section{Family Dermocarpellaceae GinSBURG-ARdRÉ ex Christensen 1980}

Dermocarpella cf. stellata Montejano et LeóNTeJera 2000. (Fig. 9)

Hemispheric cell with a thick, firm, hyaline sheath. Undivided cells have a dome shape and are 9.7-11.8 $\mu \mathrm{m}$ in wider diameter and 7.5-10.5 $\mu \mathrm{m}$ in height. Sheath $12.8-1.7 \mu \mathrm{m}$ in diameter and $9.7 \mathrm{a} 15.2 \mu \mathrm{m}$ in height. Basal cell is 3-4.6 $\mu \mathrm{m}$ high and the apical one is $3.2-5.6 \mu \mathrm{m}$ high. Some cells sometimes present a dark spot and an apical protuberance called "papilla" that also is seen in the sheath. Sometimes the cell divides parallel to the substrate. No baeocytes were observed. It is similar to the species description (LEÓN-TEJERA \& Montejano 2000), but some cells are slightly larger. First report for benthic biotopes of the Gulf of California. It is one of the six described species for the genus, and one of two reported for 
Mexico's tropical Pacific, therefore considering its small size, probably it is more common than it is reported in tropical marine biotopes.

Occurrence: It was found growing as epiphyte on Boodleopsis sp., Rhizoclonium sp., as well as on the pneumatophore cortex, next to the roots. It was relatively frequent in November 2005.

\section{Family Xenococcaceae Ercegović 1932}

Xenococcus cf. chaetomorphae SetCHELl et Gardner in Gardner 1918a. (Fig. 10)

Colony formed by subspherical to ovoid cells that can develop a polyhedral or rhomboid shape when compressed by neighboring cells in the middle of the colony. Cells with blue-green to brownish granulose cytoplasm 9-17.5 × 5-16 $\mu \mathrm{m}$ in diameter. Sheaths very evident, hyaline to yellowish, firm, 1.5-2.2 $\mu \mathrm{m}$ wide. Some cells show a dark spot near the cell wall. No baeocytes observed.

Reported for Pacific USA and Southeast Asia. It is considered by some authors as a taxonomic synonym of Dermocarpa chaetomorphae (Setchell et Gardner) P.C. Silva, however Dermocarpa is no longer considered as a valid genus.

Similar to X. pyriformis Setchell et GARDNER but with slightly larger cells and different colony and cell shape. It differs from $X$. gaditanus GonZÁLEZ in colony disposition, division pattern and its epiphytic versus epizoic habit.

A previous report for genus Xenococcus, $X$. kernerii reported by MendozA-GonzÁlez \& MATEO -CID (1985) for the Pacific of Baja California, actually is not a valid species.

Occurrence: It was found on May and November 2005. It grows on mucilage that covers part of the pneumatophore, near the roots.

\section{Xenococcus sp. (Fig. 11)}

Colony formed by an agglomeration of contiguous cells of different sizes. Cells heteropolar with a pyriform or droplet shape and a very narrow base, covered by an individual hyaline evident sheath. Cells up to $30 \times 15 \mu \mathrm{m} \mathrm{l} / \mathrm{w}$ with cytoplasm bluegreen, very granulose and frequently with a dark spot near the cell wall, Cells divide by sequential binary division originating cells of different sizes up to the smallest: blue-green spherical baeocytes 1.8-2.2 $\mu \mathrm{m}$ in diameter. Baeocyte containing sheath ruptures probably through gelatinization. Probably a new species.

Occurrence: It grows on mucilage that covers part of the pneumatophore, near the roots. Found in November 2005.

\section{Discussion}

This study is the first one in the area and in this particular biotope that describes in detail local cyanoprocaryote populations. Even though the results concern only the most representative morphotypes found on the pneumatophores, results obtained show a considerable number of new records for the Gulf of California and probably some will be later characterized as new species to science, but more detailed studies are necessary to confirm this.

Considering reports from other Latin America mangrove studies such as BRANCO et al. (1996), it is evident that Chroococcales constitute an important element of this type of biotope but there are geographical differences at the species and even generic composition. For example, we share with Branco et al. (1996) only genus Xenococcus and Chroococcus, but with different species. In the case of Nogueira \& Ferreira-Correia (2001), we share only genus Xenococcus. Pacific Mexico marine algae studies deal mainly with macroalgae, those on mangroves are few and most of them don't include descriptions. The comparison with local studies reveals a different composition, probably derived from being just a few and all of them non taxonomic studies.

For the Pacific coast of Baja California there are very few studies dealing with chroococcales, Mendoza-González \& Mateo-Cid (1985) report Dermocarpa prasina (REINSCH) BORNET, Xenococcus kerneri HANSG. and Chroococcus turgidus (KüTZING) NAGELI but Dermocarpa is not a valid genus and $X$. kerneri, that actually belongs to genus Xenotholos, and Ch. turgidus that according to KomÁreK \& ANAgnostidis (1998) are found mainly in continental waters, so probably were misidentified. Concerning Gulf of California studies, we do not share any genus or species with those of BAshan et al. (1988) and Toledo et al. (1995a) as they report only one Chroococcalean, an Aphanothece morphotype, and with LÓPEZCORTÉs (1990) also we do not share any species as his marine reports are mainly from peculiar 
biotopes such as intertidal microbial mats and shrimp ponds.

Previous non taxonomic studies performed nearby (Balandra mangroves by ToLEDo et al. 1995a) showed a particular vertical distribution where members of Oscillatoriales colonized mainly parts closer to the sediments and central parts, whereas upper parts were covered by coccal cyanobacteria such as Aphanothece. In this study we didn't find this type of evidence. Even though we didn't include Oscillatoriales in our study, concerning the Chroococcales as a group, we didn't find a common pattern in their vertical distribution. At species levels, however, some were found mainly in a particular area such as near the roots but others were found throughout all the pneumatophore, such as Chamaecalyx sp. and Chroococcus spp. All of the reported species were epiphytic either directly on the Avicennia germinans cortex, or on Rhizoclonium sp., Boodleopsis sp. or Bostrychia sp. that were also mangrove epiphytes. Concerning temporal distribution, each species also had a different pattern; some like Chroococcus sp2 had an ample temporal presence whereas others such as Dermocarpella cf. stellata were registered only for a certain season.

It is probable that the spatial and temporal distribution of several morphotypes is underestimated due sometimes to the difficulties obtaining representatives of different stages in species with complex life cycles that could allow obtaining a clear taxonomic identification.

Pristine mangroves may present higher richness that perturbed ones (SJOLING et al. 2005). In this case, Zacatecas mangrove can be considered a fairly pristine one, but the inventory is not complete and there are nonequivalent taxonomic studies in the region to compare, therefore more intensive and extensive studies in the area are needed to confirm that idea. Besides, we want to stress that as SundARARAMAN et al. (2007) remark, studies on cyanoprokaryotes associated with mangroves are important not only because of their abundance, but also of their high capability for nitrogen fixation, by which are natural inoculant candidates for future reforestation and rehabilitation of destroyed mangroves.

Mangroves constitute one of the largest ecosystems, covering around $60-70 \%$ of coastal areas of the tropics and they are now in decline, threatened by strong urban pressures; this is the case of numerous coastal areas near Zacatecas mangrove. Arid mangroves in particular cover a restricted area in Mexico and are specially distributed in the Gulf of California, therefore it is expected that further studies will increase the inventory as well as new records of cyanoprokaryotes, both for the region and this particular biotope.

\section{Acknowledgements}

This study was funded by CIBNOR-PAC-Biodiversidad del noroeste de Mexico: problemática, usos y conservación: Estudio integral de los manglares de Baja California Sur and DGAPA-UNAM-IN221410 project. Thanks to Dr. Amaury Cordero Tapia and M. en C. Ernesto Goytortua Bores for the facilities provided for observation of biological material at the Olympus BX51 microscope, Alejandra Mazariegos-Villarreal, Alma Rivera Camacho, Mabilia Urquidi and Juan José Ramírez-Rosas for collection of samples, Mónica Peralta for editing the photographs and plates; Jesus Alfredo Díaz Sánchez -INEGI for the map, Dr. Carlos H. Lechuga Deveze and Dr. Renato Mendoza for information about physicochemical parameters of Zacatecas mangrove area.

\section{References}

Baos-Estupiñan, R.A. \& Velasco, S.M. (2007): Algas asociadas a un manglar en el Pacifico Colombiano. Municipio de Buanventura - Valle de Cauca. - Rev. Biotec. Sec. Agropec. Inds. 5: 84-89.

Barrios, J.E., Márquez, B. \& Jiménez, M. (2003): Macroalgas asociadas a Rhizophora mangle L. en el Golfo de Santa Fe, Estado de Sucre, Venezuela. - Bull. Inst. Ocenogr. Venezuela Univ. Oriente. 42: 37-45.

Bashan, Y., Puente, M.E. \& Myrold, D.D. (1988): In vitro transfer of fixed nitrogen from diazotrophic cyanobacteria to black mangrove seedlings. - Microbiol. Ecol. 26: 165-170.

Branco, L.H.Z., Sant'Anna, C.L., Azevedo, M.T.P. \& Sormus, L. (1996): Cyanophyte flora from Cardoso Island mangroves, São Paulo State, Brazil. 1. Chroococcales. - Algological Studies 80: 99-111.

Burkholder, P.R. \& Almodovar, L.R. (1973): Studies on mangrove algal communities in Puerto Rico. - Fla. Sci. 36: 66-74.

Crispino, L.M.B. \& SAnT'AnNA, C.L. (2006): Cianobactérias marinhas bentônicas de ilhas costeiras do Estado de São Paulo, Brasil. - Revista Brasil. Bot. 29: 639-656.

Cruz-Madrid, C.E. (2010): Poblaciones de macroalgas asociadas a raíces y neumatóforos de mangle: estero El Tamarindo departamento de la Unión El Salvador. - 60 pp., Thesis Licenciatura, 
Universidad de El Salvador.

DAwes, C. (1998): Marine botany. - 480 pp., Second Edition. John Wiley and Sons, NY.

Flores-Verdugo, F. (1990): Algunos aspectos sobre la ecología, uso e importancia de los ecosistemas de Manglar. - In: RosA-Vélez, J. \& GonzÁlezFARÍAs, F. (eds): Temas de Oceanografía Biológica en Mexico. - pp. 22-51, Universidad Autónoma de Baja California, Ensenada, Mexico.

Gardner, N.L. (1918a): New Pacific coast marine algae II. - University of California Publications in Botany 6: 429-454.

Gardner, N.L. (1918b): New Pacific coast marine algae III. - University of California Publications in Botany 6: 455-486.

Guiry, M.D. \& Guiry, G.M. (2010): AlgaeBase. World-wide electronic publication, National University of Ireland, Galway. http://www.algaebase.org; searched on 11 October 2010.

Hoffmann, L. (1999): Marine cyanobacteria in tropical regions: diversity and ecology. - Eur. J. Phycol. 34: 371-379.

Holguin, Z.G., Bashan, \& Mendoza-Salgado, R., Amador, E., Toledo, G., VÁzquez P. \& Amador, A. (1999): La microbiología de los manglares. Bosques entre la frontera el mar y la tierra. Revista Ciencia y Desarrollo 144: 27-35.

KomÁrek, J. \& Anagnostidis, K. (1998): Cyanoprokaryota. 1. Teil: Chroococcales. - In: Ettl, H., Gärtner, G., Heynig, H. \& Mollenhauer, D. (eds): Süßwasserflora von Mitteleuropa 19/1. - 759 pp., Gustav Fischer Verlag, Stuttgart Berlin.

Laursen, W.J. \& King, R.J. (2000): The distribution and abundance of mangrove macroalgae in Woolooware Bay, New South Wales, Australia. - Bot. Mar. 43: 377-384.

León-Tejera, H. \& Montejano, G. (2000): Dermocarpella (Cyanoprokaryote/Cyanophyceae/Cyanobacteria) from the Pacific coast of Mexico. - Cryptogamie Algologie 21: 259-272.

León-Tejera, H., Montejano, G. \& Cantoral-Uriza, E. (2003): Some little known Hydrococcaceae (Cyanoprokaryota) from central Mexico. - Algological Studies 109: 363-374.

León-Tejera, H., Montejano, G. \& Gold-Morgan, M. (2005): Description of two interesting Scytonematacean populations from supratidal biotopes of the Mexican Pacific. - Algological Studies 117: 307-313.

LÓPEZ-CoRTÉs, A. (1990): Microbial mats in tidal channels at San Carlos, Baja California Sur, Mexico. - Geomicrobiol. J. 8: 69-85.

ManN, K.H. (2000): Ecology of coastal waters: with implications for management. - 406 pp., Blackwell Science, Inc. USA.

Mendoza-GonzÁlez, C. \& Mateo-Cid, L.E. (1985): Contribución al estudio florístico ficológico de la costa occidental de Baja California. - Phytologia 59: 17-33.

Montejano, G. \& LeÓn-Tejera, H. (2002): Reproduction and life cycle of Dermocarpella (Cyanophyta/Cyanobacteria). - Eur. J: Phycol. 37:323327.

Nogueira, N.M.C. \& Ferreira-Correia, M.M. 2001. Cyanophyceae/cyanobacteria in red mangrove forest at Mosquitos and Coqueiros estuaries, São Luís, state of Maranhão, Brazil. - Brazilian Journal of Biology 3: 347-356.

PeñA-SalamacA, E.J. (2008): Dinámica espacial y temporal de la biomasa algal asociada a las raíces de mangle en la Bahía de Buenaventura, costa Pacífica de Colombia. - Bol. Invest. Mar. Cost. 37: 55-70.

Phillips, A., Lambert, G., Granger, J.E. \& Steinke, T.D. (1994): Horizontal zonation of epiphytic algae associated with Avicennia marina (ForsSK.) VIERH pneumatophores at Beachwood mangroves Nature-Reserve, Durban, SouthAfrica. - Bot. Mar. 37: 567-576.

Phillips, A., Lambert, G., Granger, J. E. \& Steinke, T.D. (1996): Vertical zonation of epiphityc algae associated with Avicennia marina (Forssk.) VIERH Pneumatophores at Beachwood Mangroves Nature Reserve, Durban South Africa. - Bot. Mar. 39:167-175.

Potтs, M. (1979): Nitrogen fixation (acetylene reduction) associated with communities of heterocystous and non-heterocystous blue green-algae in mangrove forest of Sinai. - Oecologia 39: 359-373.

Potтs, M. (1980): Blue-green algae (Cyanophyta) in marine coastal environments of the Sinai Peninsula: Distribution, zonation, stratification and taxonomic diversity. - Phycologia 19: 60-73.

Potts, M. \& Whitton, B.A. (1980): Vegetation of intertidal zone of the lagoon of Aldabra, with particular reference to the photosynthetic prokaryotic communities. - Proc. R. Soc. Lond., Ser B. 208: 13-55.

Rodríguez, C. \& Stoner, A.W. (1990): The epiphyte community of mangrove roots in a tropical estuary: Distribution and biomass. - Aq. Bot. 36: 117-126.

Setchell, W.A. \& Gardner, N.L. (1919): The marine algae of the Pacific Coast of North America. Part I. Myxophyceae. - University of California Publications in Botany 8: 1-138.

Setchell, W.A. \& Gardner, N.L. (1924): Expedition of the California academy of sciences to the Gulf of California in 1921. The marine algae. Proceedings of the California Academy of Sciences, Ser. IV. 12: 695-949.

SHERIDAN, R.P. (1991): Epicaulous, nitrogen-fixing microepiphytes in a tropical mangal community, Guadeloupe, French West Indies. - Biotropica 
23: $530-541$.

Sioling, S., Mohammed, S.M., Lyimo, T.J. \& Kyaruzi, J.J. (2005): Benthic bacterial diversity and nutrient processes in mangroves: impact of deforestation. - Estu. Coast. Shelf S. 63: 397-406.

Sundararaman, M., Boopathi, T. \& Gopinath, S. (2007): Status of Mangrove Ecosystem Exploring the Potential Role of Cyanobacteria in Restoration and Afforestation. - In: SEkerbach, J. (ed.): Algae and Cyanobacteria in Extreme Environments, 11, Part 3. - pp. 209-224, Springer, Dordrecht.

TejadA-Rivas, O.L. (2002): Macroalgas asociadas a raíces de mangle: costa Pacífica de Costa Rica. Tesis de Maestría. - 64 pp. Tesis Maestría, Universidad de Costa Rica, San José Costa Rica.

Toledo, G., Bashan, Y. \& Soeldner, A. (1995a): Cyanobacteria and black mangroves in northwestern Mexico: colonization and diurnal and seasonal nitrogen fixation on aerial roots. - Can. J. Microbiol. 41: 999-1011.

Toledo, G., Bashan, Y. \& Soeldner, A. (1995b): In vitro colonization and increase in nitrogen fixation of seedling roots of black mangrove inoculated by a filamentous cyanobacteria. - Can. J. Microbiol. 41: 1012-1020.

TrainOR, F.R. (1988): Introductory phycology. - 525 pp., John Wiley \& Sons Inc, New York.

Whitmore, R.C., Brusca, R.C., León de la LuZ, J., GonzÁlez-Zamorano, P., Mendoza-Salgado, R., Amador -Silva, E.S., Holguin, Z.G., Galván-Magaña, F., Hastings, P.A., Cartron, J.E., Felger, R.S., Seminoff, J.A. \& McIvor, C.C. (2005): The ecological importance of mangroves in Baja California Sur: Conservation implications for an endagered ecosystem. - In: Cartron, J.L.E., Ceballos, G. \& Felger, R.S. (eds): Biodiversity, Ecosystems, and Conservation in Northern Mexico. - pp. 298-333, University Press, USA, Oxford.

(C) Czech Phycological Society (2011)

Recieved Sept 2010

Accepted Dec 2010 